ISSN 1678-3921

Journal homepage: www.embrapa.br/pab

For manuscript submission and journal contents, access: www.scielo.br/pab
Leticia Rios Vieira(1) (iD),

Vivianny Nayse Belo Silva(1) (1D,

Raphael Augusto das Chagas Noqueli

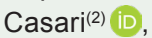

Paula Andrea Osorio Carmona(2) (iD, Carlos Antônio Ferreira de Sousa ${ }^{(3)}$ (iD) and Manoel Teixeira Souza Junior ${ }^{(2 \otimes)}$ (iD

(1) Universidade Federal de Lavras, Departamento de Química, Programa de Pós-Graduação em Biotecnologia Vegetal, Campus Universitário, Caixa Postal 3037 , CEP 37200-900 Lavras, MG, Brazil. E-mail: leticia_rios1518@hotmail.com, viviannybiologa@gmail.com

(2) Embrapa Agroenergia, Parque Estação Biológica (PqEB), s/non, Edifício Embrapa Agroenergia, Caixa Postal 40.315, CEP 70770-901 Brasília, DF, Brazil. E-mail: casari.raphael@gmail.com, osorio.carmona@gmail.com, manoel.souza@embrapa.br

(3) Embrapa Meio-Norte, Avenida Duque de Caxias, o 5.650, Bueno Aires, Caixa Postal 001, CEP 64008-780 Teresina, PI, Brazil.

E-mail: carlos.antonio@embrapa.br

$凶$ Corresponding author

Received

February 27, 2020

Accepted

August 04, 2020

How to cite

VIEIRA, L.R.; SILVA, V.N.B.; CASARI,

R.A. das C.N.; CARMONA, P.A.O.; SOUSA, C.A.F. de; SOUZA JUNIOR, M.T. Morphophysiological responses of young oil palm plants to salinity stress. Pesquisa Agropecuária Brasileira, v.55, e01835, 2020. DOI: https://doi.org/10.1590/S1678-3921. pab2020.v55.01835.

\section{Morphophysiological responses of young oil palm plants to salinity stress}

\begin{abstract}
The objective of this work was to assess the morphophysiological characteristics and the ionic imbalance in the substrate, roots, and leaves of young oil palm (Elaeis guineensis) plants under different levels of saline stress, following a substrate salinization protocol in which the level of salt was known. Bifid oil palm plants were subjected to different $\mathrm{NaCl}$ rates $(0.0,0.5,1.0,1.5$, and $2.0 \mathrm{~g} \mathrm{NaCl}$ per $100 \mathrm{~g}$ substrate on a dry basis), and their morphophysiological responses were evaluated for a period of 12-14 days. This protocol generated different levels of stress due to the gradients of electrical conductivity and water potential in the saturation extract of the substrate, according to the added $\mathrm{NaCl}$. Based on the rates of real evapotranspiration and leaf gas exchange, the osmotic effect of the salt reflected negatively on leaf temperature, on the chlorophyll content index, and on the chlorophyll fluorescence variables. The increase in $\mathrm{Na}$ and $\mathrm{Cl}$ levels in the saturation extract culminated with the increasing availability of $\mathrm{Ca}, \mathrm{K}$, and $\mathrm{Mg}$ in the solution and their accumulation in the leaves. However, the plants poorly absorbed $\mathrm{Na}$ and $\mathrm{Cl}$. The obtained results are indicative that, for a better characterization of the osmotic and ionic phases of salinity stress, it is necessary to reduce the applied level of salinity stress and to increase the evaluation period.
\end{abstract}

Index terms: Elaeis guineensis, abiotic stress, electrical conductivity, evapotranspiration, stomatal conductance, water potential.

\section{Respostas morfofisiológicas de dendezeiros jovens ao estresse de salinidade}

Resumo - O objetivo deste trabalho foi avaliar as características morfofisiológicas e o desequilíbrio iônico no substrato, nas raízes e nas folhas de plantas jovens de dendezeiro (Elaeis guineensis) sob diferentes níveis de estresse salino, seguindo protocolo de salinização do substrato em que o nível de sal era conhecido. Plantas bifídicas de dendezeiro foram submetidas a doses distintas de $\mathrm{NaCl}(0,0,0,5,1,0,1,5$ e 2,0 g de $\mathrm{NaCl}$ por $100 \mathrm{~g}$ de substrato em base seca), e suas respostas morfofisiológicas foram avaliadas por um período de 12 a 14 dias. Este protocolo gerou diferentes níveis de estresse devido aos gradientes de condutividade elétrica e potencial hídrico no extrato de saturação do substrato, de acordo com o $\mathrm{NaCl}$ adicionado. Com base nas taxas de evapotranspiração real e nas trocas gasosas foliares, o efeito osmótico do sal refletiu negativamente na temperatura da folha, no índice de conteúdo de clorofila e nas variáveis de fluorescência da clorofila. O aumento nos níveis de $\mathrm{Na}$ e $\mathrm{Cl}$ no extrato de saturação culminou com o aumento da disponibilidade de $\mathrm{Ca}, \mathrm{K}$ e $\mathrm{Mg}$ na solução e com o seu acúmulo nas folhas. No entanto, as plantas pouco absorveram $\mathrm{Na}$ e $\mathrm{Cl}$. Os resultados obtidos são indicativos de que, para uma melhor caracterização das fases osmótica e 
iônica do estresse salino, deve-se reduzir o nível de estresse salino e aumentar o período de avaliação.

Termos para indexação: Elaeis guineensis, estresse abiótico, condutividade elétrica, evapotranspiração, condutância estomática, potencial hídrico.

\section{Introduction}

Oil palm (Elaeis guineensis Jacq.), a monocotyledon crop originated from the eastern part of the African continent, is a highly important commercial source of vegetable oil (Bakoumé et al., 2015). In the 2017/2018 harvest season, it once again ranked first among the crops used for vegetable oil production, totalizing 70 million tons or $37 \%$ of all consumed vegetable oil worldwide (Statista, 2018). It also has the highest oil productivity among the commercially available oilseed crops. Despite this, only a few countries produce oil palm, with $82 \%$ of the production concentrated in Indonesia and Malaysia (FAO, 2018).

In Brazil, oil palm is mainly grown in the Amazon rainforest. In 2018, the state of Pará alone was responsible for $98 \%$ of all oil palm produced in the country (IBGE, 2019). However, of the approximately 200,000 ha cultivated with the species, only about $60 \%$ were harvested that year (Diagnóstico..., 2018; IBGE, 2019). This is considered a small area to meet the demands for palm oil in Brazil, which are increasing every year due to the government programs that encourage the use of the biodiesel derived from the crop to fuel the national fleet of trucks and buses (Programa de Produção Sustentável de Óleo de Palma no Brasil, 2010; Carvalho, 2015).

Because of this demand and the legal environmental restrictions on the use of the Amazon rainforest, with consequent logistical difficulties hindering production flow, there is a need for the cultivation of oil palm in other regions of the country. Most soils of these regions are appropriate, but the climate imposes constraints such as the lack of rainfall during certain periods of the year. In experiments in the Mid-Western region, for example, oil palm water requirements had to be met through irrigation (Azevedo et al., 2008; Costa et al., 2018). However, continuous irrigation is one of the main causes of soil salinization, especially if the water used contains high concentrations of dissolved salts.

Soil salinity is, therefore, characterized by a high concentration of soluble salts, which reduce water and osmotic potentials and increase the electrical conductivity of the soil. The presence of ions in the substrate causes a cascade effect that imbalances the entire plant metabolism, particularly water flow, the photosynthetic system, and ionic homeostasis (Parihar et al., 2015; Schiavon et al., 2017).

Saline stress has two distinct phases - osmotic and ionic -, whose duration and intensity vary according to the plant species and salt levels (Munns $\&$ Tester, 2008). The osmotic phase is characterized by the immediate inhibition of water uptake by plant roots and occurs due to the reduction of soil osmotic potential, having a similar effect to water stress. It causes many morphophysiological changes in the plant, such as: decreases in water content, growth rate, pigment content, and photosynthetic proteins; increase in the production of reactive oxygen species; and changes in the absorption and transport of several ions, cell signaling, hormonal balance, and foliar anatomy (Parida \& Das, 2005; Munns \& Tester, 2008). The ionic phase is directly related to the uptake of the $\mathrm{Na}^{+}$and $\mathrm{Cl}^{-}$ions, and to its consequences on plants. It is characterized by the toxic effects that occur in the long term, resulting in several changes (Munns \& Tester, 2008), including: senescence of older leaves; reduction in chlorophyll fluorescence and intracellular osmotic potential; and changes in the ion concentration ( $\mathrm{Na}, \mathrm{Cl}, \mathrm{K}$, and $\mathrm{Ca}$, among others) in different cell compartments and in the transport, influx, and efflux of these ions (Gupta \& Huang, 2014). Depending on the intensity and duration of saline stress and on plant tolerance mechanisms, the severity of these effects can lead to plant death (Parihar et al., 2015).

Despite these results, there are not many relevant studies addressing saline stress in oil palm. Moreover, of the works available, only a few have daily monitored the responses before and after this type of stress and even less have specified the level of stress to which the plants were subjected.

The objective of this work was to assess the morphophysiological characteristics and ionic imbalance in the substrate, roots, and leaves of young oil palm plants under different levels of saline stress, following a substrate salinization protocol in which the level of salt was known. 


\section{Materials and Methods}

All oil palm plants used in the study were regenerated from E. guineensis embryogenic calluses (AM33 genotype), supplied by Professor Sergio Motoike of Universidade Federal de Viçosa, located in the state of Minas Gerais, Brazil. The protocols and procedures implemented to regenerate the plants are described in Corrêa et al. (2015). The embryogenic calluses were transferred to a regeneration medium on January 2016 and kept in a BOD chamber at $30^{\circ} \mathrm{C}$ and a $16 / 8$-hour light/dark photoperiod. On July and December 2016, the plants regenerated in vitro were: put in $200-\mathrm{mL}$ plastic cups containing vermiculite and the Bioplant commercial substrate (Bioplant Agrícola Ltda., Nova Ponte, MG, Brazil), in a 1:1 ratio, on a dry basis; transferred to the PGW40 growth chamber (Conviron, Winnipeg, Canada), with air temperature at $25 \pm 2^{\circ} \mathrm{C}$, relative humidity at $60 \pm 10 \%$, and light intensity at $500 \pm 50 \mu \mathrm{mol} \mathrm{m} \mathrm{m}^{-2} \mathrm{~s}^{-1}$, for acclimation; and then transferred to a greenhouse at Embrapa Agroenergia, in Brasília, DF, Brazil $\left(15.732^{\circ} \mathrm{S}, 47.900^{\circ} \mathrm{W}\right)$, where they were kept until the end of the experiments.

Two salinity stress experiments were carried out in November 2017 and March 2018, respectively, using two different sets of young oil palm plants, which were selected from the collection of the in vitro regenerated plants at the greenhouse. Due to the time interval between both experiments, there was an age difference of four months between the two sets of plants used. The main environmental variables (temperature, humidity, and radiation) were monitored throughout the experimental period using data collected at a nearby meteorological station $\left(15.789^{\circ} \mathrm{S}, 47.925^{\circ} \mathrm{W}\right)$ and fluctuated according to the weather conditions.

In both experiments, the plants were grown in 5-L black plastic pots, containing $1,700 \mathrm{~g}$ of a mixture of vermiculite, soil, and the Bioplant commercial substrate (Bioplant Agrícola Ltda., Nova Ponte, MG, Brazil), in a 1:1:1 ratio, on a dry basis. The substrate mixture was fertilized using $2.5 \mathrm{~g} \mathrm{~L}^{-1}$ of the $\mathrm{N}-\mathrm{P}_{2} \mathrm{O}_{5^{-}}$ $\mathrm{K}_{2} \mathrm{O}$ formula (20-20-20).

To determine the moisture content of the substrate, ten samples containing $100 \mathrm{~g}$ fresh weight (FW) of the substrate were individually placed on Petri dishes and then oven-dried at $105^{\circ} \mathrm{C}$ for 72 hours to obtain dry weight (DW). The difference between FW and DW was the amount of water previously retained in the substrate. To determine field capacity, ten samples containing $100 \mathrm{~g}$ fresh substrate were placed in $200-\mathrm{mL}$ plastic pots, which were drilled at the bottom. Water was slowly added to the top substrate in the pots so that the excess water began to drain through the holes at the bottom. Afterwards, the pots were covered on top to avoid evaporation and maintained under drainage for approximately 6 hours to allow the total exhaustion of gravitational water. Finally, the substrate was weighed again to obtain weight at field capacity (WFC). The difference between WFC and FW corresponded to the amount of additional water necessary for the substrate to reach the maximal water-holding capacity. The sum of the amount of water previously contained in the fresh substrate and the water added to reach field capacity was considered the total amount of water in the substrate needed to reach field capacity.

The substrate salinization process included an incubation period to allow the physicochemical reactions to occur between the substrate and the added salt. The substrate samples were distributed in $200-\mathrm{mL}$ plastic pots and subjected to the following salinization rates: $0.0,0.5,1.0,1.5$, and $2.0 \mathrm{~g} \mathrm{NaCl}$ per $100 \mathrm{~g}$ substrate on a dry basis, with five replicates. $\mathrm{NaCl}$ was applied through a diluted saline solution. The amount of water used for salt dissolution was standardized and calculated by the difference between the amount of water previously present in the fresh substrate and the amount retained for the substrate to reach WFC. The substrate was then kept in the PGW40 growth chamber (Conviron, Winnipeg, Canada), with air temperature at $25 \pm 2{ }^{\circ} \mathrm{C}$, relative humidity at $60 \pm 10 \%$, and light intensity at $500 \pm 50 \mu \mathrm{mol} \mathrm{m} \mathrm{m}^{-2} \mathrm{~s}^{-1}$. Weight was monitored daily in order to return the plastic pot to its original WFC, which was done by replacing the amount of water lost by evapotranspiration with deionized water. After $0,5,10,15$, and 20 days of incubation, the substrate was suctioned through the bottom of the plastic pot with the aid of the V-700 Büchi vacuum pump (Sigma-Aldrich, St. Louis, MO, USA), for the removal of aqueous extract samples. These samples were filtered to determine electrical conductivity and water potential, using, respectively, the HI98311 conductivity meter (Hanna Instruments, Woonsocket, RI, USA) and the WP4C water potential meter (Decagon Devices, Pullman, WA, USA).

The oil palm plants in the 5-L black plastic pots were subjected to salt stress at the growth stage known 
as "bifid" saplings. The salinization of the substrate followed the same procedure previously described, in order to guarantee the stability of the variables related to saline concentration, especially electrical conductivity and water potential, during the period of saline stress. The plots, represented by young oil palm plants, were distributed in a completely randomized experimental design inside the greenhouse. The plants remained under saline stress for 17 and 12 days in the first and second experiment, respectively. The levels of salt applied were the same as those used for substrate salinization, but with four replicates.

The weight of each plastic pot containing an oil palm plant at a given salinity level was previously determined at field capacity. The difference between the initial weight of the pot at field capacity and the weight after 24 hours under evapotranspiration allowed calculating the amount of water that evaporated. The amount of lost water was replenished daily, at the same time for all plants, to return the substrate of each pot to field capacity each day. This procedure was essential to individually provide the same levels of salinity and electrical conductivity for the same treatment replicates, according to the amount of salt applied to the substrate.
Gas exchange, chlorophyll content index, and chlorophyll fluorescence were assessed in a predetermined area of the last expanded leaf, called apical leaf (leaf A). For gas exchange only, assessments were also carried out in a predetermined area of the basal leaf (leaf B). In both cases, the measurements were performed on the same leaf throughout the experiments (Figure 1).

Gas exchange was measured on the middle third of leaves $\mathrm{A}$ and $\mathrm{B}$, in a previously marked area, between 9:00 and 11:00 a.m. The 6400XT portable infrared gas analyzer (LI-COR, Lincoln, NE, USA), equipped with a $2 \times 3-\mathrm{cm}$ measuring chamber and the 6400-02B artificial light system (LI-COR, Lincoln, NE, USA), was used. The temperature of the block was set to $25^{\circ} \mathrm{C}$, photosynthetically active radiation to $1,500 \mu \mathrm{mol} \mathrm{m}{ }^{-2}$ $\mathrm{s}^{-1}$, air relative humidity inside the measuring chamber to between 50 and $60 \%$, airflow index to $400 \mu \mathrm{mol}$ $\mathrm{s}^{-1}$, and $\mathrm{CO}_{2}$ concentration to $400 \mathrm{ppm}$ in the reference cell by using the 6400-01 $\mathrm{CO}_{2}$ injector system (LICOR, Lincoln, NE, USA) with a 7.5-g $\mathrm{CO}_{2}$ cylinder. The following gas exchange variables were calculated: net $\mathrm{CO}_{2}$ assimilation rate $(A)$, stomatal conductance $(g s)$, transpiration rate $(E)$, and intercellular $\mathrm{CO}_{2}$ concentration $(\mathrm{Ci})$, based on the equations described in
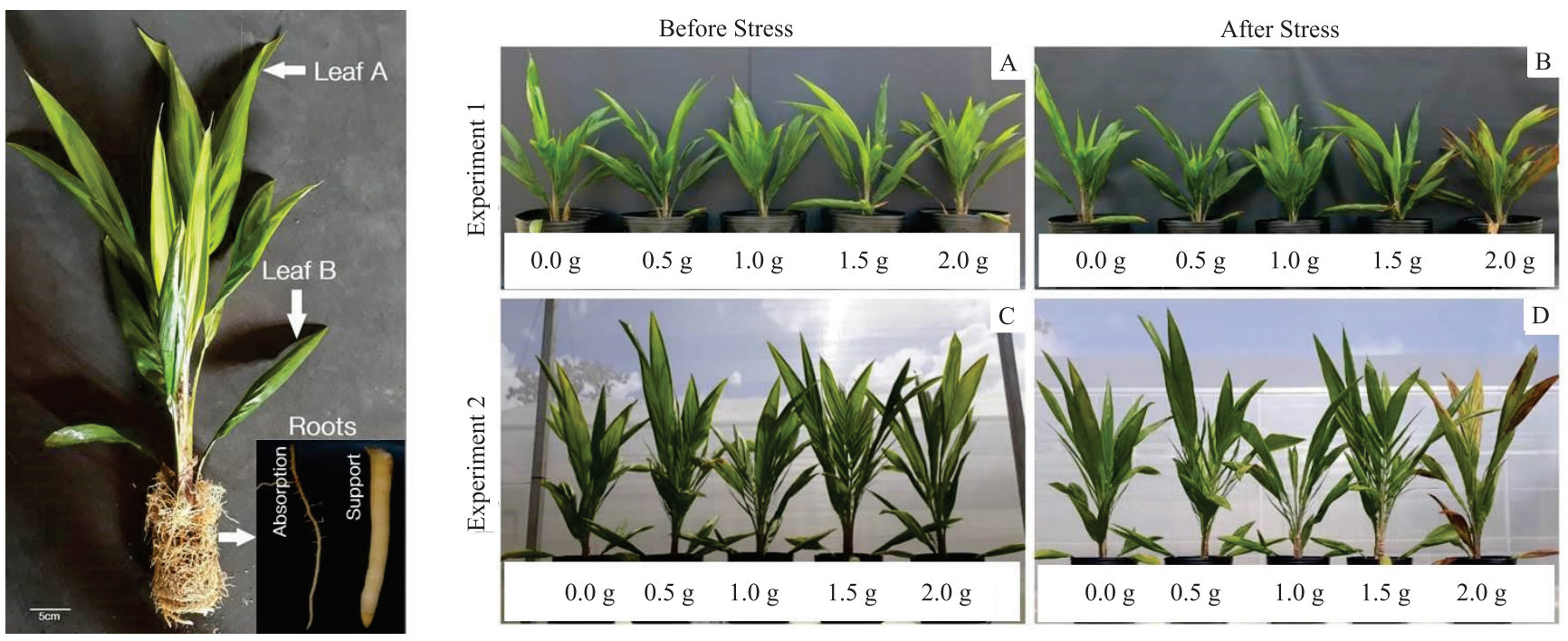

Figure 1. Young oil palm (Elaeis guineensis) plants at the bifid-sapling growth stage, evaluated in: experiment 1, before stress (A) and after 14 days under stress (B); and in experiment 2, before stress (C) and after 12 days under stress (D). On the left: plant and details of the apical (leaf A) and basal (leaf B) leaves used to collect the morphophysiological data and perform the mineral analysis; and highlight showing the support and absorption roots. On the right: plants subjected to different rates of $\mathrm{NaCl}$ added to the growing substrate (mix of vermiculite, soil, and the Bioplant commercial substrate, in a 1:1:1 ratio, on a dry basis) in greenhouse conditions. The value below each pot represents the amount of $\mathrm{NaCl}$ added to each $100 \mathrm{~g}$ substrate, oven-dried at $105^{\circ} \mathrm{C}$ for 24 hours. 
the LI-COR 6400XT user manual (Li-Cor Bioscience, 2012).

Thermal visible images were obtained with the T420 camera (FLIR Systems AB, Danderyd, Sweden), which had the following characteristics: $320 \times 240$ pixels of thermal spatial resolution, spectral response from 7.5 to $13 \mu \mathrm{m}$, uncooled microbolometer focalplane array detector, $60 \mathrm{~Hz}$ of frame rate, pixel thermal sensitivity of $0.045^{\circ} \mathrm{C}$ at $30^{\circ} \mathrm{C}$, temperature accuracy of $\pm 2^{\circ} \mathrm{C}$ or $2 \%$ of reading (whichever is greater) at $25^{\circ} \mathrm{C}$, lens of $25^{\circ}$, and weight of $0.88 \mathrm{~kg}$ including the battery. Following the principles of infrared thermography (Usamentiaga et al., 2014), the thermal imager was set up for the environmental conditions at the time of image capture, which included distance of plant leaves, reflected temperature obtained by the aluminum foil method, atmospheric temperature, and air relative humidity. Thermal leaf emissivity was set to 0.98 . For this purpose, the plant leaves were considered as grey bodies in which emissivity is constant and independent of the wavelength for the spectral range of 7.5-13 $\mu \mathrm{m}$. The thermographic images were analyzed by the FLIR Tools software, version 6.3 (FLIR Systems AB, Danderyd, Sweden), and the average temperature of the leaves was extracted from geometric figures drawn along the leaf blade.

The chlorophyll content index was measured on leaf $\mathrm{A}$, in the same portion used to determine gas exchange and relative water content. This index was analyzed using the CCM-200 Plus chlorophyll meter (Opti-Sciences Inc., Hudson, NH, USA). Measures were taken in five different points of the selected leaf portion. The averaged values were used.

The chlorophyll fluorescence technique, also known as the saturation pulse method, was used to determine the following parameters with the MINI-PAM portable chlorophyll fluorometer (Heinz Walz GmbH, Effeltrich, Germany): maximum fluorescence yield on dark-adapted plants (Fm), minimum fluorescence yield on dark-adapted plants (Fo), and maximum PSII quantum yield $(\mathrm{Fv} / \mathrm{Fm})$. These measurements were performed on leaf $\mathrm{A}$, in the same portion used to measure the chlorophyll content index. The used device was configured to provide an initial fluorescence measurement light with a frequency of $0.6 \mathrm{KHz}$ and intensity at level 2, with an amplifier factor of the detector electronic signal set up at level 1 . The intensity of the saturating light pulse was set up at level 12. The piece of leaf to be evaluated was previously kept in the dark for at least 1 hour with the aid of the DLC8 leaf clip (Heinz Walz GmbH, Effeltrich, Germany). For the measurement procedure, the probe tip of the fluorometer was coupled to the leaf clip, which was attached to the leaf. Then, the leaf clip shutter was opened to expose the leaf piece to be evaluated. After $2 \mathrm{~s}$, enough time for the initial fluorescence signal to stabilize (without the influence of actinic light), the start button was pressed, triggering the maximum photosystem II quantum yield, calculated using the WinControl software (Heinz Walz GmbH, Effeltrich, Germany). Initially, a routine recorded the Fo generated by the initial measurement light and, then, the software triggered a pulse of saturating light and recorded the Fm. From these two variables, the internal algorithm present in the WinControl software automatically calculated $\mathrm{Fv} / \mathrm{Fm}$, according to the equation described by Genty et al. (1989): Fv/Fm = (Fm - Fo $/ \mathrm{Fm}$.

For biomass determination, plants were harvested at the end of each experiment. Their component parts, i.e., shoots and roots, were weighed to determine fresh biomass and, then, dried in a forced-air oven, at $65^{\circ} \mathrm{C}$, until constant weight to obtain dry biomass. The two types of oil palm plant roots were used, namely: absorption roots, which are thin, branched, and with absorbent hairs; and support roots, which are thick, unbranched, and with a smooth surface (Figure 1).

To determine mineral content, samples were collected from leaves A and B, support and absorption roots, and the substrate before and after plant growth. The dried samples were ground in the TE-680 Wiley mill (Tecnal, Piracicaba, SP, Brazil), passed through a 1-mm sieve (20 mesh), and then subjected to mineral extraction by the standard methods used in laboratory routine (Vieira, 2019).

All data were subjected to the Shapiro-Wilk and Bartlett tests to check for normality of errors and homogeneity of variances, respectively. Once the basic requirements were met, the means were subjected to the analysis of variance. Data on the electrical conductivity and water potential of the substrate were subjected to the regression analysis. Time was considered as a qualitative factor for gas exchange, canopy temperature, chlorophyll content index, chlorophyll fluorescence, and biomass. Means were compared by the Scott-Knott test, at 5\% probability, using the SISVAR software, version 5.6 (Ferreira, 
2019). The means of the mineral content in the substrate, leaves, and roots were also subjected to the regression analysis.

\section{Results and Discussion}

The saturation extract of the substrate before the addition of $\mathrm{NaCl}$ showed a low electrical conductivity (EC) and a slightly positive water potential $(\psi w)$ (Figure 2). Since the theoretical maximum value of $\psi \mathrm{w}$ is equal to zero, the positive ones can be the result of a measurement error, which is higher in the type of equipment used when the $\psi \mathrm{w}$ value approaches zero. The addition of $\mathrm{NaCl}$ to the substrate caused imbalances in the ionic and osmotic components, triggering a rapid increase in the EC and a proportional decrease in the $\psi \mathrm{w}$ of the saturation extract. In general, during 20 days of incubation, EC and $\psi \mathrm{w}$ slightly increased and decreased, respectively (Figure 2), which are common changes after salt addition (Rivero et al., 2014; Qiu et al., 2017; Schiavon et al., 2017).

A
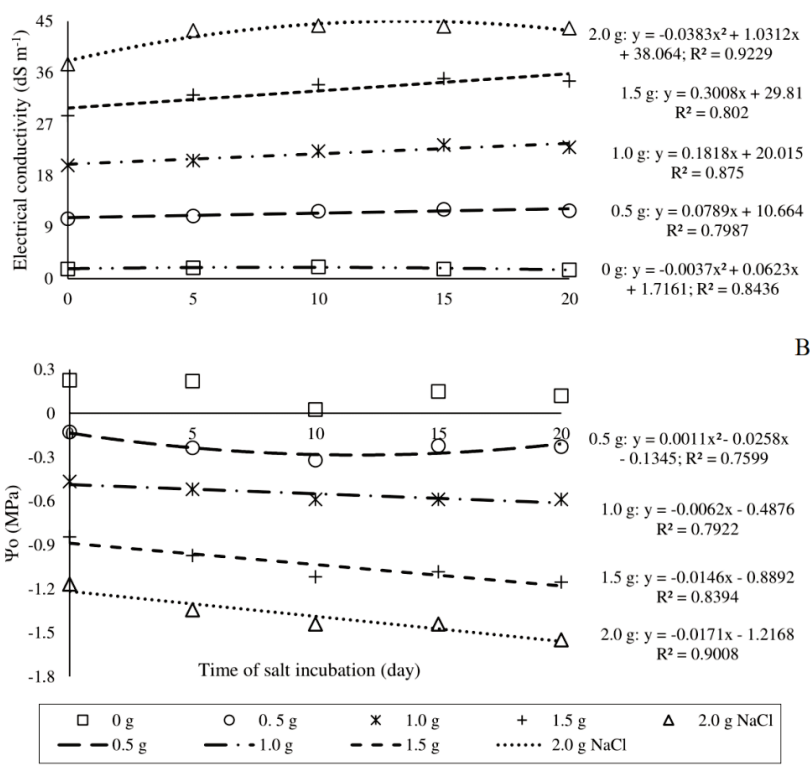

Figure 2. Electrical conductivity (A) and water potential (B) of the substrate (mix of vermiculite, soil, and the Bioplant commercial substrate, in a 1:1:1 ratio, on a dry basis) saturation extract after the addition of different $\mathrm{NaCl}$ rates, without any plants. The trend lines follow their respective line equations and coefficient of determination $\left(\mathrm{R}^{2}\right)$.
However, those two variables derived from the salt content in the substrate only underwent minor changes during the incubation period. This means that most of the salt was available in the solution, rather than retained in the substrate. These results may be due to the methodology used to extract the saline solution for the measurements. In any case, the values obtained for both variables were proportional to the salt rate added to the substrate, implying that oil palm plants subjected to the same rate were also exposed to the same levels of EC and $\psi \mathrm{w}$ throughout the experiments.

The addition of salt to a medium causes an increase in the content of total ions and in the ability of the aqueous solution to conduct an electric current (Clesceri et al., 1998). By measuring the $\mathrm{EC}$ of a solution, it is possible to quickly and efficiently determine the degree of mineralization and the variation in the content of dissolved salts (Clesceri et al., 1998). Furthermore, the increase in solute concentration, which is the chemical potential of a watering system, is one of the factors that contributes to the reduction of the $\psi \mathrm{w}$ of a solution (Taiz \& Zeiger, 2013).

Before the imposition of saline stress (time zero), real evapotranspiration rates did not differ between both groups of plants. However, 24 hours after the addition of different amounts of $\mathrm{NaCl}$, the evapotranspiration rates reduced proportionally to the rate of salt added to the substrate (Figure 3). Therefore, the higher the salt rate, the lower the real evapotranspiration rate. This pattern of response was maintained throughout the experiment, regardless of the daily oscillations caused by temporal fluctuations in the weather-related variables. It should be noted that the daily water evapotranspiration rates were higher in the second experiment due to the larger size of the plants.

Other studies dealing with saline stress in plants reported this same type of behavior (Al-Busaidi \& Yamamoto, 2011; Toledo et al., 2017; Xin et al., 2016). However, the obtained results depend on a careful standardization of plant age and size, of the salt rate added to the substrate, and of the daily replenishment of the water lost by evapotranspiration to return to field capacity, as was done in the present work. This standardization was fundamental to ensure the level of salinity to which the plants were subjected and to maintain relatively constant the levels of EC and $\psi \mathrm{w}$ of the solution. These last two variables, which depend on the salt rate, will induce modifications in the plant 
metabolism, from roots to shoots, to seek strategies to adapt to salt stress.

Before the addition of $\mathrm{NaCl}$ to the substrate, oil palm plants showed the highest gas exchange rates $(A, g s$, and $E$ ) and the lowest $C i$, especially in leaf A (Table 1). However, on the fifth day after the onset of saline stress, the gas exchange rates decreased proportionally to the increase in the concentration of $\mathrm{NaCl}$, especially in leaf $\mathrm{B}$; this drop accentuated on the eighth day. In general, the results showed that the longer the exposure to saline stress, the older the leaf, and the higher the $\mathrm{NaCl}$ concentration, the faster is the drop in the gas exchange rates. (Table 1). Similar results were observed in studies carried out by ShaarMoshe et al. (2017) with Brachypodium distachyon (L.) P.Beauv. and by Rivero et al. (2014) with Solanum lycopersicon $\mathrm{L}$. The main reason for the reduction in the photosynthetic rates of plants under salt stress is the reduction in the osmotic potential of the root medium, followed by the accumulation of the $\mathrm{Na}$ and $\mathrm{Cl}$ ions
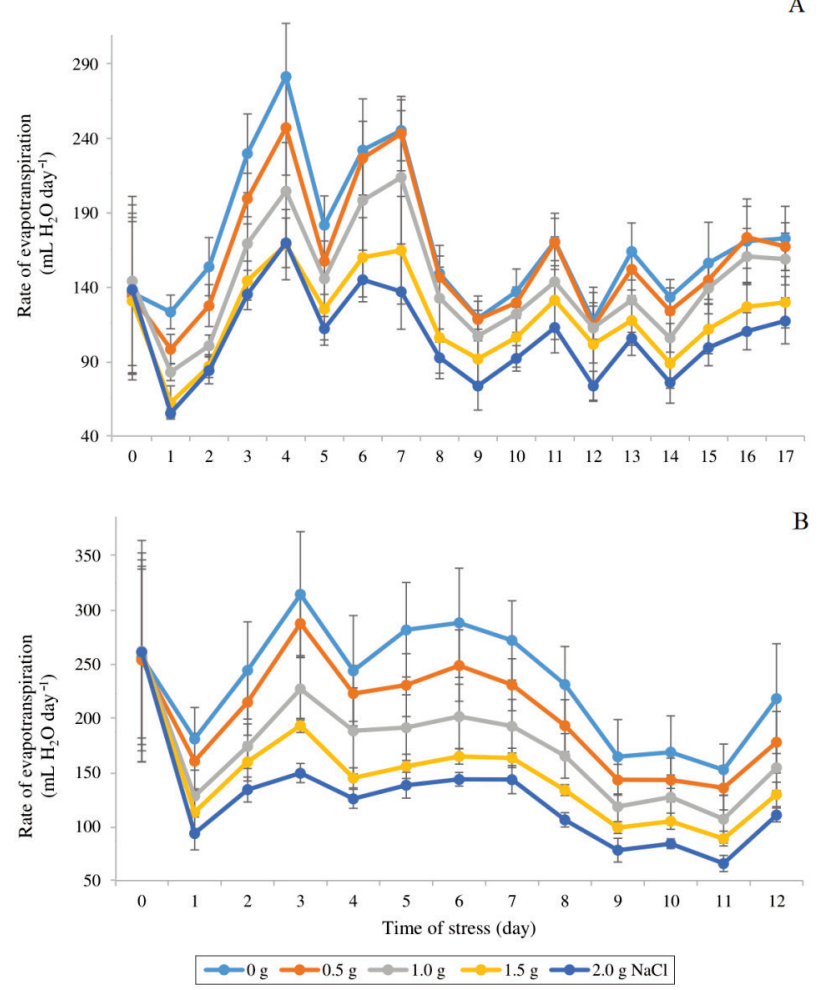

Figure 3. Daily evapotranspiration rate with different amounts of $\mathrm{NaCl}$ added to the substrate (mix of vermiculite, soil, and the Bioplant commercial substrate, in a 1:1:1 ratio, on a dry basis) cultivated with young oil palm (Elaeis guineensis) plants, in experiment 1 (A) and experiment 2 (B). Bars indicate the mean standard deviation $(n=4)$. in the leaves (Parihar et al., 2015). In fact, in the oil palm plants under study, the changes in the stomatal conductance rates were closely related to $\mathrm{NaCl}$ and the $\psi w$ of the saturation extract and, consequently, to the evapotranspiration rates.

The efficiency of the gas exchange of a plant under salt stress is linked directly to its capacity to maintain the homeostasis of water relations (Negrão et al., 2017). Stomatal closure, induced rapidly by the reduction in water absorption in the osmotic phase, causes a decline in stomatal conductance and the diffusion of $\mathrm{CO}_{2}$ into the leaf mesophyll (Chaves et al., 2009), restricting the supply of $\mathrm{CO}_{2}$ to the ribulose bisphosphate carboxylase/oxygenase (Rubisco) enzyme. Therefore, the maintenance of leaf gas exchanges under saline conditions is one of the evidences of salt stress tolerance (Munns \& Tester, 2008; Harris et al., 2010; Negrão et al., 2017). From this point of view, oil palm can be considered as salinity sensitive because its gas exchange rates were reduced proportionally to the increase in $\mathrm{NaCl}$. Moreover, the accumulation of intercellular $\mathrm{CO}_{2}$, especially at the higher level of 2.0 $\mathrm{g} \mathrm{NaCl}$ and in older leaves (Table 1), suggests that the activity of Rubisco and/or other enzymes responsible for carbon reduction in the leaf mesophyll may have been affected.

Before the addition of salt to the substrate (time zero), no differences were observed in leaf temperature among the groups of plants. However, as the $\mathrm{NaCl}$ concentration in the substrate increased, the leaf temperature also increased (Figure 4). Therefore, 12 days after the addition of salt to the substrate, the leaf temperature of the plants subjected to the two highest rates differed statistically from those of the others. This result is further evidence that saline stress restricted the rates of water absorption and gas exchange, and, consequently, the cooling capacity of the leaves. Differences in salt stress levels between plants have been determined by thermography, a nondestructive, remote sensing technique (Munns \& Tester, 2008; Sirault et al., 2009; Negrão et al., 2017). Its principle builds on the dynamic flow of water in a plant, which means that the higher the rates of water absorption, stomatal conductance, and transpiration, the lower the leaf temperature and salt stress level (Negrão et al., 2017).

Besides the decrease in gas exchange rates, another common effect of saline stress on plants is the 
Table 1. Gas exchange rates in leaves of young oil palm (Elaeis guineensis) plants subjected to different rates of $\mathrm{NaCl}$ added to the substrate (mix of vermiculite, soil, and the Bioplant commercial substrate, in a 1:1:1 ratio, on a dry basis) in greenhouse conditions ${ }^{(1)}$.

\begin{tabular}{|c|c|c|c|c|c|}
\hline \multirow[t]{2}{*}{ Parameter $^{(2)}$} & \multirow[t]{2}{*}{ Leaf $^{(3)}$} & \multirow[t]{2}{*}{$\mathrm{g} \mathrm{NaCl}$ per $100 \mathrm{~g}$ substrate } & \multicolumn{3}{|c|}{ Time of salt stress (day) } \\
\hline & & & 0 & 5 & 8 \\
\hline \multirow{10}{*}{$A\left(\mu \mathrm{mol} \mathrm{CO}{ }_{2} \mathrm{~m}^{-2} \mathrm{~s}^{-1}\right)$} & \multirow{5}{*}{ A } & 0 & $9.83 \mathrm{Aa} \alpha$ & $7.76 \mathrm{Ab} \alpha$ & $7.20 \mathrm{Ab} \alpha$ \\
\hline & & 0.5 & $7.26 \mathrm{Ca} \alpha$ & $7.24 \mathrm{Aa} \alpha$ & $4.24 \mathrm{Bb} \alpha$ \\
\hline & & 1.0 & 7.19Ca $\alpha$ & $3.91 \mathrm{Bb} \alpha$ & $2.24 \mathrm{Cc} \alpha$ \\
\hline & & 1.5 & $7.38 \mathrm{Ca} \alpha$ & $1.45 \mathrm{Cb} \alpha$ & $1.56 \mathrm{Cb} \alpha$ \\
\hline & & 2.0 & $8.67 \mathrm{Ba} \alpha$ & $-0.18 \mathrm{Db} \alpha$ & $-0.47 \mathrm{Db} \alpha$ \\
\hline & \multirow{5}{*}{ B } & 0 & $5.90 \mathrm{Ba} \beta$ & $6.38 \mathrm{Aa} \beta$ & $3.99 \mathrm{Ab} \beta$ \\
\hline & & 0.5 & $6.92 \mathrm{Aa} \alpha$ & $4.95 \mathrm{Bb} \beta$ & $2.38 \mathrm{Bc} \beta$ \\
\hline & & 1.0 & $6.15 \mathrm{Ba} \alpha$ & $0.88 \mathrm{Cb} \beta$ & $0.96 \mathrm{Cb} \beta$ \\
\hline & & 1.5 & $7.68 \mathrm{Aa} \alpha$ & $-0.11 \mathrm{Cb} \beta$ & $0.03 \mathrm{Cb} \beta$ \\
\hline & & 2.0 & $6.84 \mathrm{Aa} \beta$ & $0.62 \mathrm{Cb} \alpha$ & $0.52 \mathrm{Cb} \alpha$ \\
\hline \multirow{10}{*}{$g s\left(\mathrm{~mol} \mathrm{H}_{2} \mathrm{O} \mathrm{m}^{-2} \mathrm{~s}^{-1}\right)$} & \multirow{5}{*}{ A } & 0 & $0.18 \mathrm{Aa} \alpha$ & $0.12 \mathrm{Ab} \alpha$ & $0.12 \mathrm{Ab} \alpha$ \\
\hline & & 0.5 & $0.11 \mathrm{Ca} \alpha$ & $0.10 \mathrm{Aa} \alpha$ & $0.06 \mathrm{Bb} \alpha$ \\
\hline & & 1.0 & $0.14 \mathrm{Ba} \alpha$ & $0.06 \mathrm{Bb} \alpha$ & $0.05 \mathrm{Bb} \alpha$ \\
\hline & & 1.5 & $0.20 \mathrm{Aa} \alpha$ & $0.05 \mathrm{Bb} \alpha$ & $0.05 \mathrm{Bb} \alpha$ \\
\hline & & 2.0 & $0.20 \mathrm{Aa} \alpha$ & $0.00 \mathrm{Cb} \alpha$ & $0.00 \mathrm{Cb} \alpha$ \\
\hline & \multirow{5}{*}{ B } & 0 & $0.07 \mathrm{Bb} \beta$ & $0.11 \mathrm{Aa} \alpha$ & $0.07 \mathrm{Ab} \beta$ \\
\hline & & 0.5 & $0.10 \mathrm{Aa} \alpha$ & $0.04 \mathrm{Bb} \beta$ & $0.04 \mathrm{Bb} \beta$ \\
\hline & & 1.0 & $0.11 \mathrm{Aa} \beta$ & $0.02 \mathrm{Cb} \beta$ & $0.02 \mathrm{Bb} \beta$ \\
\hline & & 1.5 & $0.12 \mathrm{Aa} \beta$ & $0.00 \mathrm{Cb} \beta$ & $0.00 \mathrm{Bb} \beta$ \\
\hline & & 2.0 & $0.13 \mathrm{Aa} \beta$ & $0.02 \mathrm{Cb} \alpha$ & $0.01 \mathrm{Bb} \alpha$ \\
\hline \multirow{10}{*}{$C_{i}\left(\mu \mathrm{mol} \mathrm{m}{ }^{-2} \mathrm{~s}^{-1}\right)$} & \multirow{5}{*}{ A } & 0 & $275.50 \mathrm{Aa} \alpha$ & $255.71 \mathrm{Ba} \alpha$ & $274.22 \mathrm{Ca} \alpha$ \\
\hline & & 0.5 & 247.19Aa $\alpha$ & $261.87 \mathrm{Ba} \alpha$ & $247.79 \mathrm{Ca} \alpha$ \\
\hline & & 1.0 & $277.16 \mathrm{Aa} \alpha$ & $313.18 \mathrm{Ba} \alpha$ & $275.45 \mathrm{Ca} \alpha$ \\
\hline & & 1.5 & $298.16 \mathrm{Aa} \alpha$ & $318.29 \mathrm{Ba} \beta$ & $351.27 \mathrm{Ba} \beta$ \\
\hline & & 2.0 & $295.61 \mathrm{Ac} \alpha$ & $555.04 \mathrm{Ab} \alpha$ & $904.72 \mathrm{Aa} \alpha$ \\
\hline & \multirow{5}{*}{ B } & 0 & $230.71 \mathrm{Aa} \alpha$ & $251.58 \mathrm{Ba} \alpha$ & $234.49 \mathrm{Ca} \alpha$ \\
\hline & & 0.5 & $256.72 \mathrm{Aa} \alpha$ & $234.43 \mathrm{Ba \alpha}$ & $250.92 \mathrm{Ca} \alpha$ \\
\hline & & 1.0 & $269.94 \mathrm{Aa} \alpha$ & $284.62 \mathrm{Ba} \alpha$ & $273.04 \mathrm{Ca} \alpha$ \\
\hline & & 1.5 & $266.60 \mathrm{Ac} \alpha$ & $426.38 \mathrm{Ab} \alpha$ & $544.41 \mathrm{Ba} \alpha$ \\
\hline & & 2.0 & $264.11 \mathrm{Ac} \alpha$ & $372.08 \mathrm{Ab} \beta$ & $637.50 \mathrm{Aa} \beta$ \\
\hline \multirow{10}{*}{$E\left(\mathrm{mmol} \mathrm{H}_{2} \mathrm{O} \mathrm{m}^{-2} \mathrm{~s}^{-1}\right)$} & \multirow{5}{*}{ A } & 0 & 4.09Aa $\alpha$ & $2.28 \mathrm{Ab} \alpha$ & $2.52 \mathrm{Ab} \alpha$ \\
\hline & & 0.5 & $2.51 \mathrm{Ba} \alpha$ & $2.11 \mathrm{Aa} \alpha$ & $1.63 \mathrm{Bb} \alpha$ \\
\hline & & 1.0 & $2.90 \mathrm{Ba} \alpha$ & $1.30 \mathrm{Bb} \alpha$ & $1.26 \mathrm{Bb} \alpha$ \\
\hline & & 1.5 & $3.73 \mathrm{Aa} \alpha$ & $1.17 \mathrm{Bb} \alpha$ & $1.40 \mathrm{Bb} \alpha$ \\
\hline & & 2.0 & $3.72 \mathrm{Aa} \alpha$ & $0.07 \mathrm{Cb} \alpha$ & $0.13 \mathrm{Cb} \alpha$ \\
\hline & \multirow{5}{*}{ B } & 0 & $1.47 \mathrm{Bb} \beta$ & $2.14 \mathrm{Aa} \alpha$ & $1.65 \mathrm{Ab} \beta$ \\
\hline & & 0.5 & 2.39Aa $\alpha$ & $1.54 \mathrm{Bb} \beta$ & $0.57 \mathrm{Bc} \beta$ \\
\hline & & 1.0 & $2.46 \mathrm{Aa} \alpha$ & $0.36 \mathrm{Cb} \beta$ & $0.37 \mathrm{Bb} \beta$ \\
\hline & & 1.5 & $2.63 \mathrm{Aa} \beta$ & $0.13 \mathrm{Cb} \beta$ & $0.11 \mathrm{Bb} \beta$ \\
\hline & & 2.0 & $2.16 \mathrm{Aa} \beta$ & $0.07 \mathrm{c}$ & $0.07 \mathrm{Bb} \alpha$ \\
\hline
\end{tabular}

(1) Means followed by equal letters do not differ by the Scott-Knott test, at $5 \%$ probability. Lowercase, uppercase, and Greek letters compare, respectively, time under stress, $\mathrm{NaCl}$ concentrations, and leaf types. ${ }^{(2)} \mathrm{A}$, net $\mathrm{CO}_{2}$ assimilation rate; $g s$, stomatal conductance; $\mathrm{Ci}$, intercellular $\mathrm{CO}_{2}$ concentration; and $E$, transpiration rate. ${ }^{(3)} \mathrm{A}$, apical leaf; and $\mathrm{B}$, basal leaf. 
reduction in chlorophyll content (Lutts et al., 1996; Cha-um et al., 2009; Chutipaijit et al., 2011) and in the photochemical efficiency of photosynthetic pigments (Rivero et al., 2014; Bendaly et al., 2016; Kalaji et al., 2018; Rahneshan et al., 2018). In both experiments, young oil palm plants had a similar leaf chlorophyll content index before the onset of saline stress (Figure 5). However, in the first one, the $\mathrm{NaCl}$ rates above $1.0 \mathrm{~g}$ promoted a drop in the values obtained for the index, starting on the second day of stress and accentuating proportionally to the level of salt as the stress period went on. In the second, the values of the index were only half of the ones of the first experiment and did not repeat the same pattern of behavior.
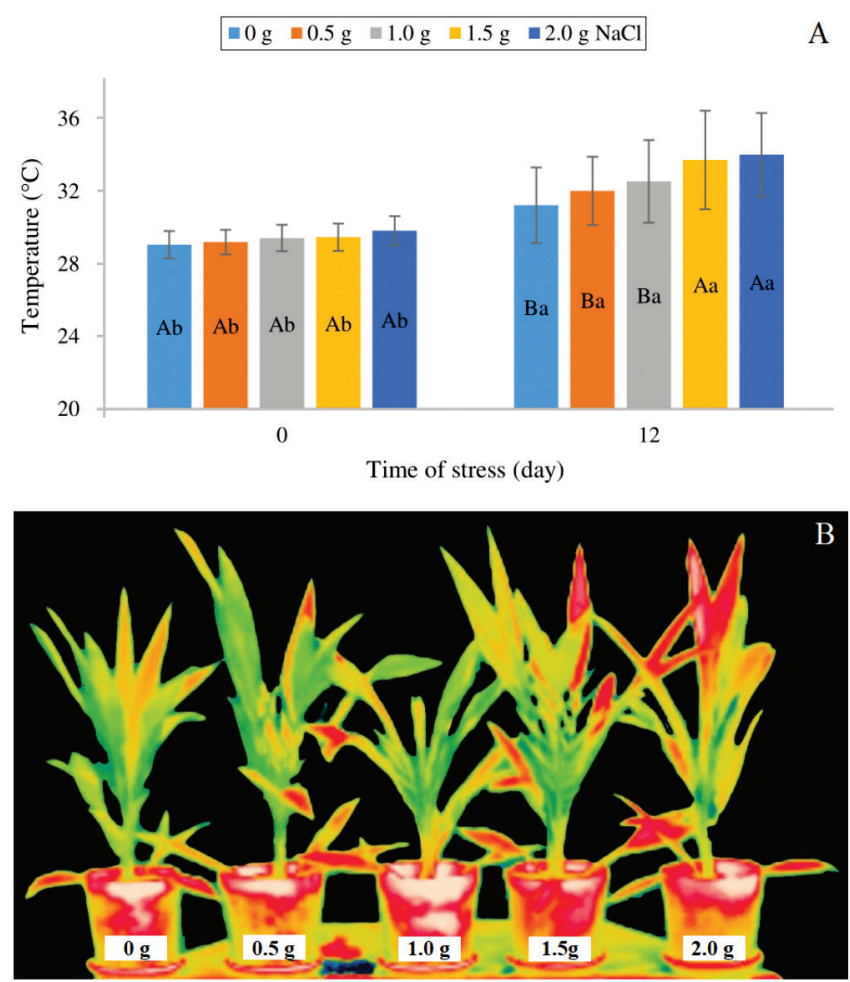

Figure 4. Average temperature on the leaves of young oil palm (Elaeis guineensis) plants on day 0 and 12 of saline stress (A) and thermal images on day 12 (B) due to different rates of $\mathrm{NaCl}$ added to the substrate (mix of vermiculite, soil, and the Bioplant commercial substrate, in a 1:1:1 ratio, on a dry basis). Uppercase letters compare the means from different $\mathrm{NaCl}$ rates on the same day, and lowercase letters compare the same $\mathrm{NaCl}$ rate on different days. Means followed by equal letters do not differ by the Scott-Knott test, at $5 \%$ probability. Bars indicate the mean standard deviation $(n=4)$.
In the first experiment, the addition of $\mathrm{NaCl}$ to the substrate changed all leaf chlorophyll fluorescence variables in the young oil palm plants due to stress severity and duration. At the end of the stress period, Fo suffered a significative drop at the maximum salt rate used (Figure 6). Fm was strongly affected by 1.0 $\mathrm{g}$ salt or higher on the second day, but recovered at the intermediate levels of $\mathrm{NaCl}$, so that, at the end of the evaluation period, only the maximum rate caused a significant decrease. $\mathrm{Fv} / \mathrm{Fm}$ also reduced on the second day with $1.5 \mathrm{~g} \mathrm{NaCl}$; however, as $\mathrm{Fm}$, it recovered and only dropped at the highest rate of $2.0 \mathrm{~g} \mathrm{NaCl}$ on the last day of stress. In the second experiment, the small changes that occurred throughout the stress period in the chlorophyll fluorescence variables appeared to be random or due to leaf age, with little or no relation to the $\mathrm{NaCl}$ levels in the substrate.

As expected, the drop in the chlorophyll content index (Figure 5) corresponded to a decrease in Fm and $\mathrm{Fv} / \mathrm{Fm}$ (Figure 6), at least on the second day of saline stress. The initial drop in $\mathrm{Fv} / \mathrm{Fm}$, which is related to

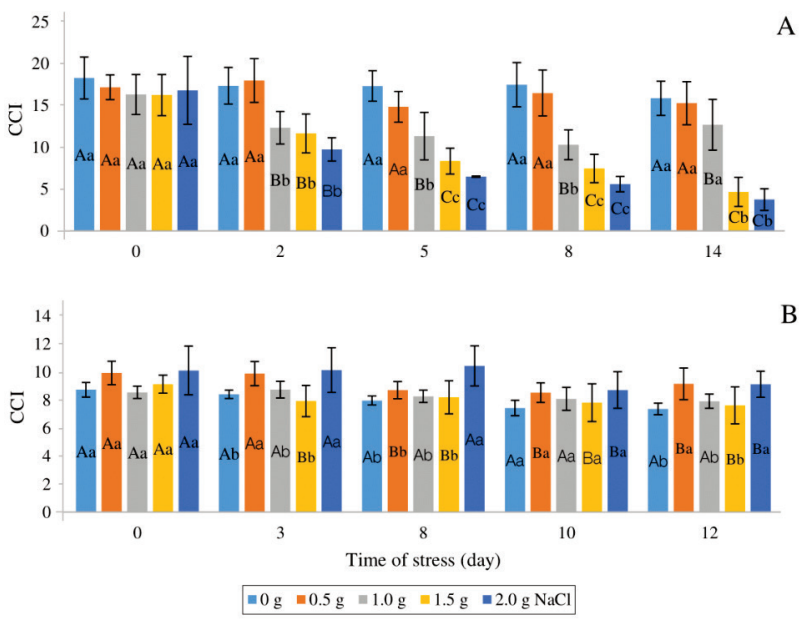

Figure 5. Chlorophyll content index (CCI) in the apical leaf of oil palm (Elaeis guineensis) plants subjected to different rates of $\mathrm{NaCl}$ added to the substrate (mix of vermiculite, soil, and the Bioplant commercial substrate, in a 1:1:1 ratio, on a dry basis), in experiment 1 (A) and experiment 2 (B). Uppercase letters compare the average measurements obtained with the same $\mathrm{NaCl}$ rates on different days, while lowercase letters compare the averages obtained on the same day with different $\mathrm{NaCl}$ rates. Means followed by equal letters do not differ by the Scott-Knott test, at 5\% probability. Bars indicate the mean standard deviation $(n=4)$. 
the loss of efficiency in the capture and transport of electrons from plants under salt stress, was associated with the decrease in Fm and not with the increase in
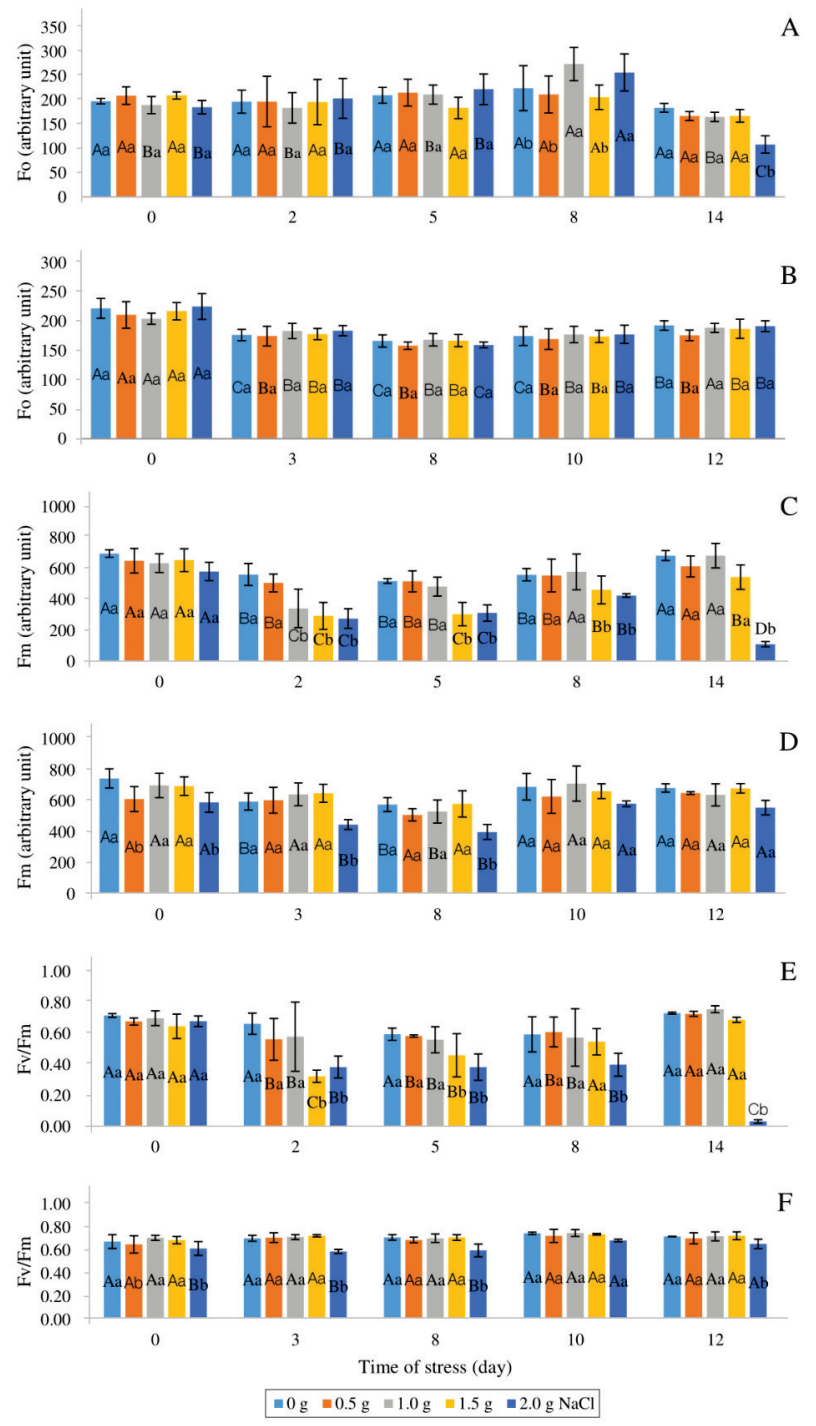

Figure 6. Initial fluorescence in the dark (Fo) (A), maximum fluorescence in the dark (Fm) (B), and maximum quantum yield of photosystem II ( Fv/Fm) (C) in the apical leaf of young oil palm (Elaeis guineensis) plants subjected to different rates of $\mathrm{NaCl}$ added to the substrate (mix of vermiculite, soil, and the Bioplant commercial substrate, in a 1:1:1 ratio, on a dry basis). 1, experiment 1; and 2, experiment 2. Uppercase letters compare the average measurements obtained with the same $\mathrm{NaCl}$ rates on different days, while lowercase letters compare the averages obtained on the same day with different $\mathrm{NaCl}$ rates. Means followed by equal letters do not differ by the Scott-Knott test, at 5\% probability. Bars indicate the mean standard deviation $(n=4)$.
Fo; the latter variable suffered a drop at the maximum salt rate of $2.0 \mathrm{~g}$ and on the fourteenth day of stress. Together, these results suggest that, with chlorophyll degradation, which occurred in the young oil palm plants due to saline stress, the chloroplasts lost part of the antenna structure responsible for capturing light energy. However, they kept their membrane system accountable for the photochemical flux of electrons at least up to the rate of $1.5 \mathrm{~g} \mathrm{NaCl}$. It is interesting to observe that, even in the case of oil palm, a species considered sensitive to salinity, the addition of salt to the older plants did not cause considerable changes in pigment content and, probably, in the reaction center and antennae of photosystem II.

The substrates salinized by $\mathrm{NaCl}$ showed minerals with altered properties and composition, since the exchangeable cations - such as $\mathrm{Na}, \mathrm{Cl}, \mathrm{Ca}, \mathrm{K}$, and $\mathrm{Mg}$ - increased proportionally to the increase of the salt concentration in the substrate (Figure 7).

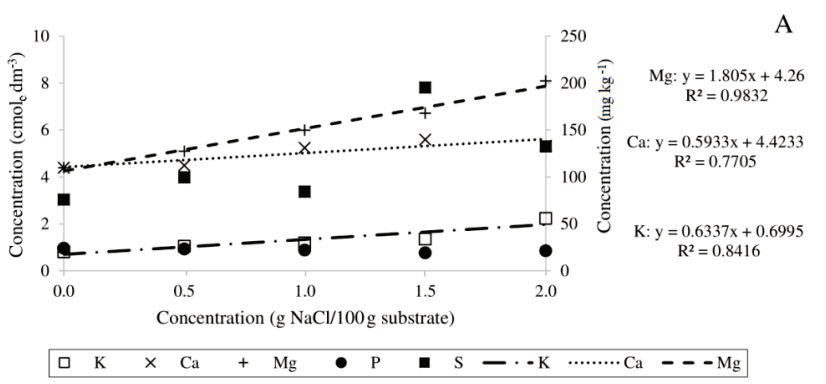

B

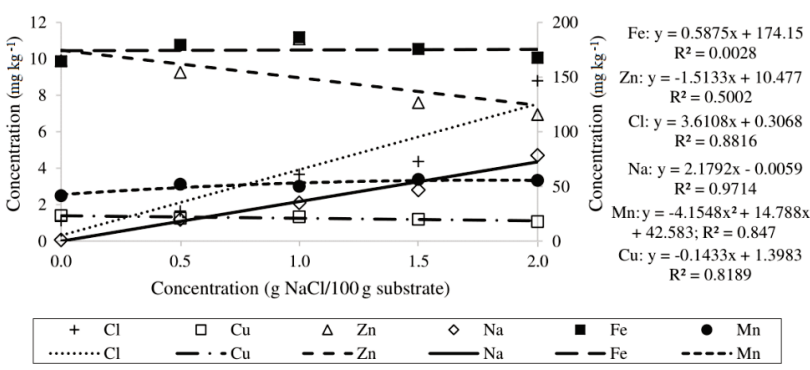

Figure 7. Mineral composition - including macro- (A) and micronutrients (B) - of the substrate (mix of vermiculite, soil, and the Bioplant commercial substrate, in a 1:1:1 ratio, on a dry basis) receiving different rates of $\mathrm{NaCl}$. The concentration of the minerals whose symbols are filled in black corresponds to the secondary y axis (right). The trend lines follow their respective line equations and coefficient of determination $\left(\mathrm{R}^{2}\right)$. 
Consequently, there was a proportional increase in the base saturation, cation exchange capacity, and EC of the saturation extract. The other mineral elements, however, did not differ significantly.

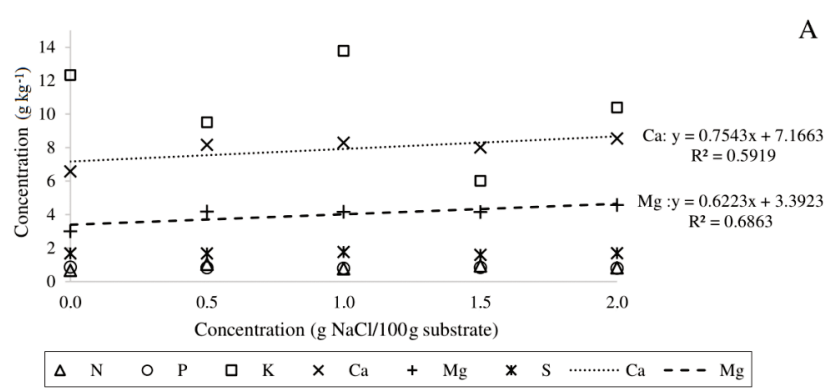

C

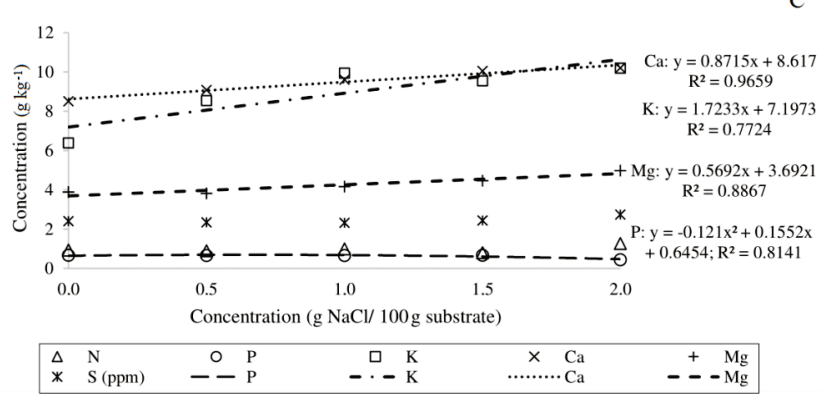

$\mathrm{E}$

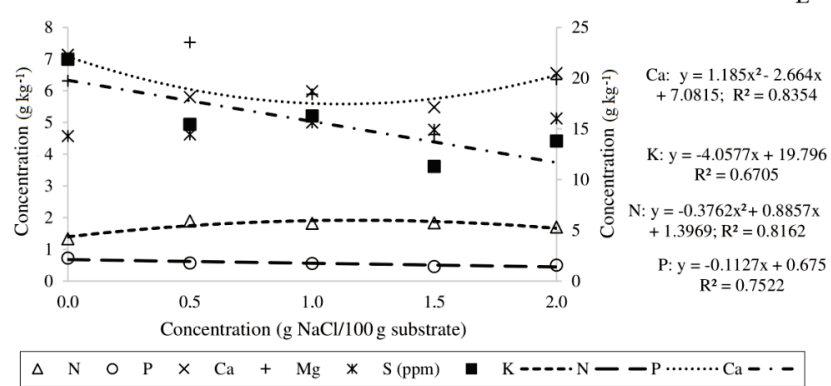

G

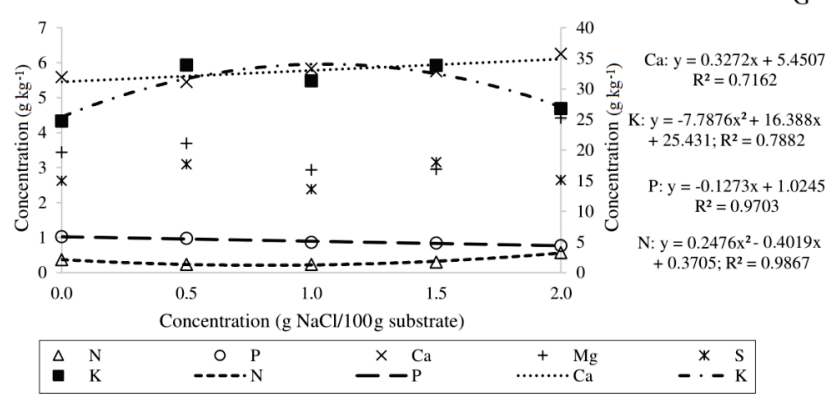

Both support and absorption roots had low levels of $\mathrm{Cl}$. Even so, $\mathrm{Cl}$ showed a slight upward trend in the absorption roots with increasing $\mathrm{NaCl}$ levels in the growing substrate (Figure 8). In the absorption roots,
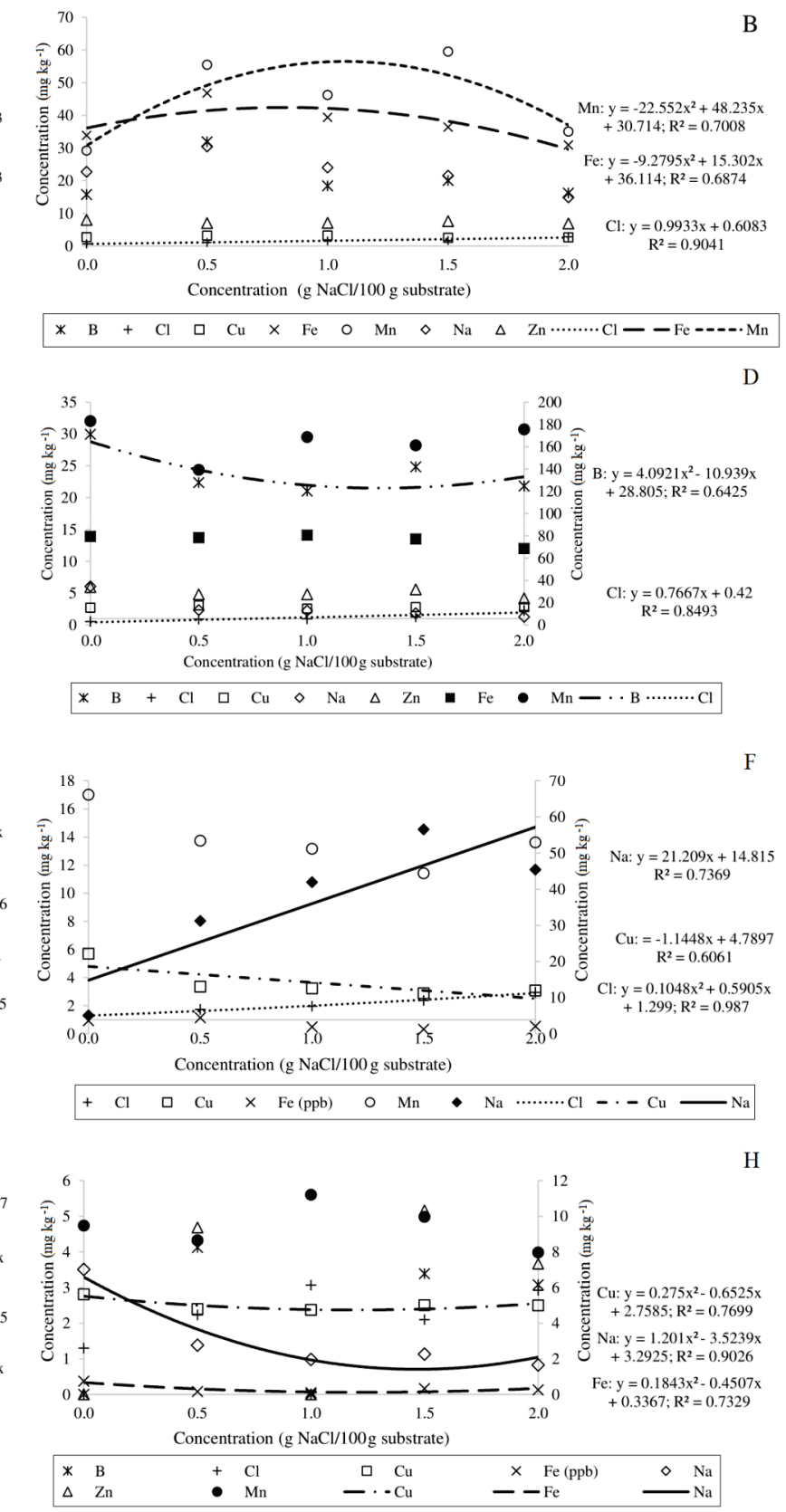

Figure 8. Mineral composition of the apical leaf (A and B), basal leaf (C and D), absorption roots ( $\mathrm{E}$ and $\mathrm{F}$ ), and support roots $(\mathrm{G}$ and $\mathrm{H})$ of young oil palm (Elaeis guineensis) plants subjected to different rates of $\mathrm{NaCl}$ added to the substrate (mix of vermiculite, soil, and the Bioplant commercial substrate, in a 1:1:1 ratio, on a dry basis). A, C, E, and G, macronutrients; and $\mathrm{B}, \mathrm{D}, \mathrm{F}$, and $\mathrm{H}$, micronutrients. The concentration of the minerals whose symbols are filled in black corresponds to the secondary y axis (right). The trend lines follow their respective line equations and coefficient of determination $\left(\mathrm{R}^{2}\right)$. 
the content of the $\mathrm{Na}$ ion was higher and $\mathrm{Na}$ increased with increasing salt levels in the substrate. Regarding other mineral elements, there was only a decrease in the $\mathrm{K}$ and $\mathrm{Fe}$ contents in the support and absorption roots, respectively.

The mineral composition of both types of leaves selected for analysis was influenced by the increasing $\mathrm{NaCl}$ rates (Figure 8). In general, the concentrations of $\mathrm{Cl}$ were low in both leaves, but there was a slight increase as the $\mathrm{NaCl}$ level increased in the substrate. Although the levels of $\mathrm{Na}$ were higher in leaf $\mathrm{A}$, they did not differ statistically as a function of the amount of $\mathrm{NaCl}$ added to the substrate. The content of $\mathrm{Ca}$ and $\mathrm{Mg}$ increased in leaves $\mathrm{A}$ and $\mathrm{B}$, whereas the content of $\mathrm{K}$ only increased in leaf $\mathrm{B}$; the other elements did not differ.

The first phase of salt stress on plants, known as the osmotic phase, is associated with high concentrations of $\mathrm{Na}$ and $\mathrm{Cl}$ in the solution, which are proportional to the amount of $\mathrm{NaCl}$ added to the medium (Munns $\&$ Tester, 2008). As a consequence, there is a rapid reduction in osmotic potential, which restricts water absorption and, therefore, reduces transpiration rates (Munns \& Tester, 2008; Parihar et al., 2015). The second phase of saline stress, known as the ionic phase, occurs more slowly and depends on the saline concentration to which the plant was subjected, as well as on exposure time and the plant's capacity to accumulate or expel toxic ions (Munns \& Tester, 2008; Kumari et al., 2015). In the case of oil palm plants, despite the proportional increase in $\mathrm{Na}$ and $\mathrm{Cl}$ availability in the substrate due to the amount of added salt, roots and leaves showed low levels of both ions, mainly of $\mathrm{Cl}$ (Figure 8). Moreover, the availability of $\mathrm{Cl}$ in the substrate solution was relatively proportional to its contents in both types of roots and leaves, whereas $\mathrm{Na}$ increased in the absorption roots, but remained the same in the leaves.

In the first experiment, $\mathrm{NaCl}$ caused a reduction in the FW and DW of the roots of the oil palm plants, regardless of the amount added to the substrate, but had no effect on the shoots (Figure 9 A). In the second experiment, with older and larger plants, saline stress
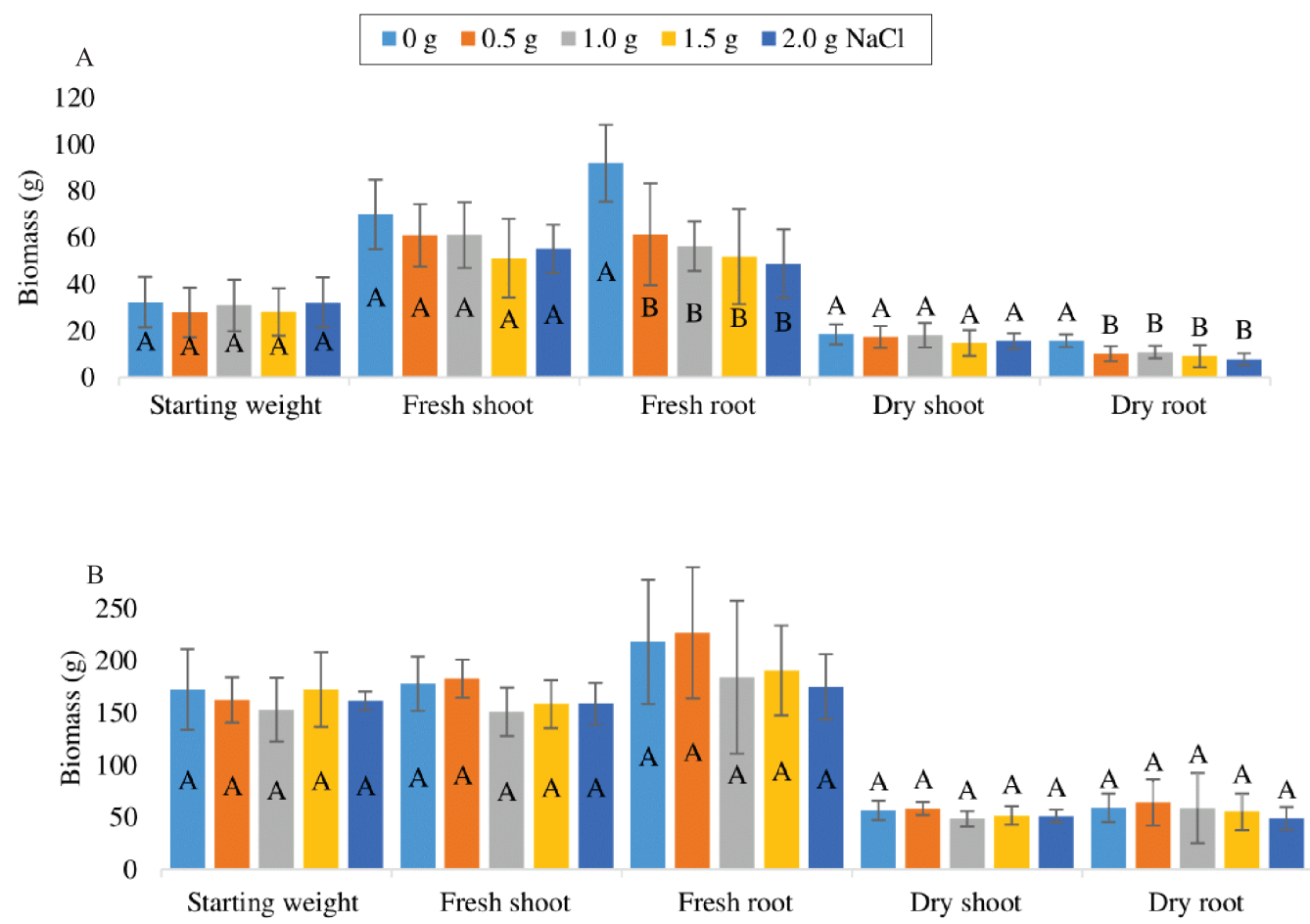

Figure 9. Fresh (A) and dry (B) biomass of the shoots and roots of young oil palm (Elaeis guineensis) plants subjected to different rates of $\mathrm{NaCl}$ added to the substrate (mix of vermiculite, soil, and the Bioplant commercial substrate, in a 1:1:1 ratio, on a dry basis). 1, experiment 1; and 2, experiment 2. Uppercase letters compare the means in the same $\mathrm{NaCl}$ rate on different days. Means followed by equal letters do not differ by the Scott-Knott test, at $5 \%$ probability. Bars indicate the mean standard deviation $(n=4)$. 
did not affect the accumulation of biomass in roots and shoots (Figure 9 B). However, in both cases, brownish and necrotic areas appeared on the leaves of the plants subjected to the highest rates of $\mathrm{NaCl}$ in the substrate. It should be noted that, despite their age difference, all the plants used for the experiments were quite young, since they still had bifid leaves and only a few other leaves. Therefore, the growth of the young oil palm plants was constrained under salt stress, as expected, due to the restriction in water absorption by the roots, the reduction in photosynthetic rates (Hare et al., 1998; Munn \& Tester, 2008; Rivero et al., 2014), and the increase in pigment breakdown (Gupta \& Huang, 2014; Mekawy et al., 2015; Muscolo et al., 2015). However, the reduction in the growth rate due to salt stress is not necessarily the same in all plant organs, since biomass is preferably allocated to the aerial part of the plant, resulting in a lower accumulation in the roots (Negrão et al., 2017).

During saline stress, in addition to the reallocation of photoassimilates, energy expenditure is reduced to a minimum necessary for organ survival (Munn \& Tester, 2008; Xin et al., 2016). Therefore, some time is needed for metabolic changes to reflect in biomass production, which depends on the rates of metabolic activity of the plant or a specific organ. Probably, the oil palm plants used in the present study had a low metabolic activity, as may be inferred from their low gas exchange rates compared with adult plants (Dufrene \& Saugier, 1993). Another possibility is that, because this is a species that lives for dozens of years (Corley \& Tinker, 2003), the time of stress imposed in this study was too short.

\section{Conclusions}

1. The protocol developed in this study for assessing oil palm (Elaeis guineensis) responses to saline stress is successful in generating different levels of stress by gradients of electrical conductivity and water potential in the saturation extract of the substrate, according to the added $\mathrm{NaCl}$.

2. Young oil palm plants at the two highest $\mathrm{NaCl}$ rates (1.5 and $2.0 \mathrm{~g} \mathrm{NaCl}$ per $100 \mathrm{~g}$ substrate) show extensive leaf necrosis already at two weeks after the onset of the stress, indicating that lower salt rates $\left(\leq 1.0\right.$ g per $100 \mathrm{~g}$ substrate or $\left.\leq 20 \mathrm{dS} \mathrm{m}^{-1}\right)$ are necessary to better characterize the morphophysiological responses to salinity stress.

3. The short period of evaluation allows the establishment of the osmotic phase of salinity stress, but not of the ionic one, indicating that, for a better characterization of the osmotic and ionic phases, it is necessary to decrease the level of applied salinity stress and to increase the assessment period.

\section{Acknowledgments}

To Professor Sergio Motoike from Universidade Federal de Viçosa (UFV), for supplying the oil palm embryogenic calluses that generated the plants used in the study; to Coordenação de Aperfeiçoamento de Pessoal de Nível Superior (Capes), for supporting the first and second authors through the Graduate Program in Plant Biotechnology at Universidade Federal de Lavras (UFLA); and to Financiadora de Estudos e Projetos (Finep), for grant (01.13.0315.02 - DendêPalm project).

\section{References}

AL-BUSAIDI, A.; YAMAMOTO, T. The impact of seawater salinity on evapotranspiration and plant growth under different meteorological conditions. In: GEROSA, G. (Ed.). From measurements to agricultural and environmental applications. London: IntechOpen, 2011. DOI: https://doi.org/10.5772/17034.

AZEVEDO, J.A. de; JUNQUEIRA, N.T.V.; BRAGA, M.F.; SÁ, M.A.C. de. Parâmetros de irrigação durante o período seco em plantas jovens de dendê cultivadas no Cerrado. Planaltina: Embrapa Cerrados, 2008. 4p. (Embrapa Cerrados. Comunicado técnico, 146)

BAKOUMÉ, C.; WICKNESWARI, R.; SIJU, S.; RAJANAIDU, N.; KUSHAIRI, A.; BILlOTTE, N. Genetic diversity of the world's largest oil palm (Elaeis guineensis Jacq.) field genebank accessions using microsatellite markers. Genetic Resources and Crop Evolution, v.62, p.349-360, 2015. DOI: https://doi.org/10.1007/s10722-014-0156-8.

BENDALY, A.; MESSEDI, D.; SMAOUI, A.; KSOURI, R.; BOUCHEREAU, A.; ABDELLY, C. Physiological and leaf metabolome changes in the xerohalophyte species Atriplex halimus induced by salinity. Plant Physiology and Biochemistry, v.103, p.208-218, 2016. DOI: https://doi.org/10.1016/j.plaphy.2016.02.037.

CARVALHO, C.M. de. A expansão sustentável do cultivo da palma para a produção de biodiesel no Brasil: o caso do estado do Pará. 2015. 105p. Tese (Doutorado) - Universidade Federal do Rio de Janeiro, Rio de Janeiro.

CHA-UM, S.; BORIBOONKASET, T.; PICHAKUM, A.; KIRDMANEE, C. Multivariate physiological indices for salt 
tolerance classification in indica rice (Oryza sativa L. spp. indica). General and Applied Plant Physiology, v.35, p.75-87, 2009.

CHAVES, M.M.; FLEXAS, J.; PINHEIRO, C. Photosynthesis under drought and salt stress: regulation mechanisms from whole plant to cell. Annals of Botany, v.103, p.551-560, 2009. DOI: https://doi.org/10.1093/aob/men125.

CHUTIPAIJIT, S.; CHA-UM, S.; SOMPORNPAILIN, K. High contents of proline and anthocyanin increase protective response to salinity in Oryza sativa L. spp. indica. Australian Journal of Crop Science, v.5, p.1191-1198, 2011.

CORLEY, R.H.V.; TINKER, P.B. The oil palm. $4^{\text {th }}$ ed. Oxford: Black Well Science, 2003. 562p.

CORRÊA, T.R.; MOTOIKE, S.Y.; COSER, S.M.; SILVEIRA, G. da; RESENDE, M.D.V. de; CHIA, G.S. Estimation of genetic parameters for in vitro oil palm characteristics (Elaeis guineensis Jacq.) and selection of genotypes for cloning capacity and oil yield. Industrial Crops and Products, v.77, p.1033-1038, 2015. DOI: https://doi.org/10.1016/j.indcrop.2015.09.066.

COSTA, S.J. da; ERASMO, E.A.L.; TAVARES, T.C. de O.; SILVA, J. Respostas fisiológicas de dendê submetidas ao estresse hídrico em condições do Cerrado. Revista Brasileira de Agropecuária Sustentável, v.8, p.92-99, 2018. DOI: https://doi.org/10.21206/ rbas.v8i4.3055.

DIAGNÓSTICO da produção sustentável da palma de óleo. Brasília: Mapa, 2018. Available at: <www.abrapalma.org/pt/ wp-content/uploads/2018/06/DIAGNOSTICO_PALMA1.pdf $>$. Accessed on: Nov. 212019.

DUFRENE, E.; SAUGIER, B. Gas exchange of oil palm in relation to light, vapour pressure deficit, temperature and leaf age. Functional Ecology, v.7, p.97-104, 1993. DOI: https://doi.org/10.2307/2389872.

ClESCERI, L.S.; GREENBERG, A.E.; EATON, A.D. (Ed). Standard methods for the examination of water and wastewater. $20^{\text {th }}$ ed. Washington: American Public Health Association, 1998.

FAO. Food and Agriculture Organization of the United Nations. Faostat: oil palm. 2018. Available at: <www.fao.org/faostat/ en/\#data/QC >. Accessed on: Nov. 212019.

FERREIRA, D.F. Sisvar: a computer analysis system to fixed effects split plot type designs. Revista Brasileira de Biometria, v.37, p.529-535, 2019. DOI: https://doi.org/10.28951/rbb.v37i4.450.

GENTY, B.; BRIANTAIS, J.-M.; BAKER, N.R. The relationship between the quantum yield of photosynthetic electron transport and quenching of chlorophyll fluorescence. Biochimica et Biophysica Acta (BBA) - General Subjects, v.990, p.87-92, 1989. DOI: https://doi.org/10.1016/S0304-4165(89)80016-9.

GUPTA, B.; HUANG, B. Mechanism of salinity tolerance in plants: physiological, biochemical, and molecular characterization. International Journal of Genomics, art. ID 701596, 2014. DOI: https://doi.org/10.1155/2014/701596.

HARE, P.D.; CRESS, W.A.; VAN STADEN, J. Dissecting the roles of osmolyte accumulation during stress. Plant, Cell \& Environment, v.21, p.535-553, 1998. DOI: https://doi.org/10.1046/ j.1365-3040.1998.00309.x.
HARRIS, B.N.; SADRAS, V.O.; TESTER, M. A water-centred framework to assess the effects of salinity on the growth and yield of wheat and barley. Plant and Soil, 336, p.377-389, 2010. DOI: https://doi.org/10.1007/s11104-010-0489-9.

IBGE. Instituto Brasileiro de Geografia e Estatística. Produção Agrícola Municipal: Tabela 5457: área plantada ou destinada à colheita, área colhida, quantidade produzida, rendimento médio e valor da produção das lavouras temporárias e permanentes. 2019. Available at: <https://sidra.ibge.gov.br>. Accessed on: Nov. 21 2019.

KALAJI, H.M.; BĄBA, W.; GEDIGA, K.; GOLTSEV, V.; SAMBORSKA, I.A.; CETNER, M.D.; DIMITROVA, S.; PISZCZ, U.; BIELECKI, K.; KARMOWSKA, K.; DANKOV, K.; KOMPAŁA-BĄBA, A. Chlorophyll fluorescence as a tool for nutrient status identification in rapeseed plants. Photosynthesis Research, v.136, p.329-343, 2018. DOI: https://doi.org/10.1007/ s11120-017-0467-7.

KUMARI, A.; DAS, P.; PARIDA, A.K.; AGARWAL, P.K. Proteomics, metabolomics, and ionomics perspectives of salinity tolerance in halophytes. Frontiers in Plant Science, v.6, art.537, 2015. DOI: https://doi.org/10.3389/fpls.2015.00537.

LI-COR BIOSCIENCES. Using the LI-6400/ LI-6400XT: Portable Photosynthesis System. version 6. Lincoln, 2012.

LUTTS, S.; KINET, J.M.; BOUHARMONT, J. Effects of salt stress on growth, mineral nutrition and proline accumulation in relation to osmotic adjustment in rice (Oryza sativa L.) cultivars differing in salinity resistance. Plant Growth Regulation, v.19, p.207-218, 1996. DOI: https://doi.org/10.1007/BF00037793.

MEKAWY, A.M.M.; ASSAHA, D.V.M.; YAHAGI, H.; TADA, Y.; UEDA, A.; SANEOKA, H. Growth, physiological adaptation, and gene expression analysis of two Egyptian rice cultivars under salt stress. Plant Physiology and Biochemistry, v.87, p.17-25, 2015. DOI: https://doi.org/10.1016/j.plaphy.2014.12.007.

MUNNS, R.; TESTER, M. Mechanisms of salinity tolerance. Annual Review of Plant Biology, v.59, p.651-681, 2008. DOI: https://doi.org/10.1146/annurev.arplant.59.032607.092911.

MUSCOLO, A.; JUNKER, A.; KLUKAS, C.; WEIGELTFISCHER, K.; RIEWE, D.; ALTMANN, T. Phenotypic and metabolic responses to drought and salinity of four contrasting lentil accessions. Journal of Experimental Botany, v.66, p.54675480, 2015. DOI: https://doi.org/10.1093/jxb/erv208.

NEGRÃO, S.; SCHMÖCKEL, S.M.; TESTER, M. Evaluating physiological responses of plants to salinity stress. Annals of Botany, v.119, p.1-11, 2017. DOI: https://doi.org/10.1093/aob/ mew191.

PARIDA, A.K.; DAS, A.B. Salt tolerance and salinity effects on plants: a review. Ecotoxicology and Environmental Safety, v.60, p.324-349, 2005. DOI: https://doi.org/10.1016/j. ecoenv.2004.06.010.

PARIHAR, P.; SINGH, S.; SINGH, R.; SINGH, V.P.; PRASAD, S.M. Effect of salinity stress on plants and its tolerance strategies: a review. Environmental Science and Pollution Research, v.22, p.4056-4075, 2015. DOI: https://doi.org/10.1007/s11356-014-3739-1. 
PROGRAMA DE PRODUÇÃO SUSTENTÁVEL DE ÓLEO DE PALMA NO BRASIL. Brasília: Mapa, 2010.

QIU, R.; LIU, C.; WANG, Z.; YANG, Z.; JING, Y. Effects of irrigation water salinity on evapotranspiration modified by leaching fractions in hot pepper plants. Scientific Reports, v.7, art.7231, 2017. DOI: https://doi.org/10.1038/s41598-017-07743-2.

RAHNESHAN, Z.; NASIBI, F.; MOGHADAM, A.A. Effects of salinity stress on some growth, physiological, biochemical parameters and nutrients in two pistachio (Pistacia vera L.) rootstocks. Journal of Plant Interactions, v.13, p.73-82, 2018. DOI: https://doi.org/10.1080/17429145.2018.1424355.

RIVERO, R.M.; MESTRE, T.C.; MITTLER, R.; RUBIO, F.; GARCIA-SANCHEZ, F.; MARTINEZ, V. The combined effect of salinity and heat reveals a specific physiological, biochemical and molecular response in tomato plants. Plant, Cell \& Environment, v.37, p.1059-1073, 2014. DOI: https://doi.org/10.1111/pce.12199.

SCHIAVON, M.; PEDROZA, A.; LEINAUER, B.; SUAREZ, D.L.; BAIRD, J.H. Varying evapotranspiration and salinity level of irrigation water influence soil quality and performance of perennial ryegrass (Lolium perenne L.). Urban Forestry \& Urban Greening, v.26, p.184-190, 2017. DOI: https://doi.org/10.1016/j.ufug.2017.01.006.

SHAAR-MOSHE, L.; BLUMWALD, E.; PELEG, Z. Unique physiological and transcriptional shifts under combinations of salinity, drought, and heat. Plant Physiology, v.174, p.421-434, 2017. DOI: https://doi.org/10.1104/pp.17.00030.

SIRAULT, X.R.R.; JAMES, R.A.; FURBANK, R.T. A new screening method for osmotic component of salinity tolerance in cereals using infrared thermography. Functional Plant Biology, v.36, p.970-977, 2009. DOI: https://doi.org/10.1071/FP09182.

STATISTA. The Statistics Portal. 2018. Available at: $<$ www.statista.com/statistics/263937/vegetable-oils-globalconsumption>. Accessed on: Nov. 212019.

TAIZ, L.; ZEIGER, E. Fisiologia vegetal. 5.ed. Porto Alegre: Artmed, 2013.

TOLEDO, J.V.; ZOLNIER, S.; SILVA, T.G.F. da; BOEHRINGER, D.; STEIDLE NETO, A.J. Alterations on the evapotranspiration of sugarcane cultivars under distinct salinity levels applied in the fertigation. Engenharia Agrícola, v.37, p.940-952, 2017. DOI: https://doi.org/10.1590/1809-4430-eng.agric.v37n5p940-952/2017.

USAMENTIAGA， R.; VENEGAS， P.; GUEREDIAGA， J.; VEGA, L.; MOLLEDA, J.; BULNES, F.G. Infrared thermography for temperature measurement and non-destructive testing. Sensors, v.14, p.12305-12348, 2014. DOI: https://doi.org/10.3390/ s140712305.

VIEIRA, L.R. Respostas morfofisiológicas, metabolômicas e transcriptômicas da palma de óleo (Elaeis guineensis) aos estresses abióticos de seca e salinidade. 2019. 160p. Tese (Doutorado) - Universidade Federal de Lavras, Lavras.

XIN, H.; PEILING, Y.; SHUMEI, R.; YUNKAI, L.; GUANGYU, L.; LIANHAO, L. Quantitative response of oil sunflower yield to evapotranspiration and soil salinity with saline water irrigation.

International Journal of Agricultural and Biological Engineering, v.9, p.63-73, 2016. DOI: https://doi.org/10.3965/j. ijabe.20160902.1683. 